Reprod. Nutr. Dévelop., 1983, 23 (2 B), 429-435.

\title{
A method for quantifying insulin sensitivity in vivo in the anesthetized rat: the euglycemic insulin clamp technique coupled with isotopic measurement of glucose turnover
}

\author{
Anne-Françoise BURNOL, Armelle LETURQUE, P. FERRE, J. GIRARD \\ Laboratoire de Physiologie du Développement, Collège de France, \\ 11. place Marcelin-Berthelot, 75231 Paris Cedex 05, France.
}

\begin{abstract}
Summary. The euglycemic insulin clamp technique coupled with isotopic measurement of the glucose utilization rate $\left(\left[3-{ }^{3} \mathrm{H}\right]\right.$ glucose $)$, described previously in man, has been adapted to characterize and quantify insulin sensitivity in vivo in the rat. Only $30 \mathrm{~min}$ were needed for the exogenous glucose infusion rate, the specific activity of $\left[3-{ }^{3} \mathrm{H}\right]$ glucose and the plasma insulin to reach a steady-state value. During the next $30 \mathrm{~min}$ of the experiment, blood glucose was maintained at a constant basal level with a coefficient of variation of $2.3 \%$. Plasma insulin was $48 \pm 4 \mu \mathrm{U} / \mathrm{ml}$ and glucose utilization was $1.84 \pm 0.07 \mathrm{mg} / \mathrm{min}$ in anesthetized female rats in the basal state. During euglycemic insulin clamp, plasma insulin was $302 \pm 24 \mu \mathrm{U} / \mathrm{ml}$, glucose utilisation was increased by $53 \pm 10 \%$ and endogenous glucose production was decreased by $76 \pm 3 \%$. By studying several insulin concentrations in different groups of rats, we hope to be able to characterize insulin resistance during pregnancy and to determine whether hepatic or peripheral tissues are responsible for this insulin resistance.
\end{abstract}

\section{Introduction.}

Several techniques have been used for the in vivo assessment of overall sensitivity to insulin in man and in laboratory animals. These methods include the conventional glucose and insulin tolerance tests as well as a recently described technique in which insulin and glucose, infused simultaneously with epinephrine and propranolol (Reaven et al., 1976) or somatostatin (Harano et al., 1977 ; Nagulesparan et al., 1979), suppress endogenous insulin secretion and achieve steady-state plasma levels of glucose and insulin. As the steady-state insulin concentrations always attain the same value, the level of the steady-state plasma glucose provides an estimate of the ability of the insulin to stimulate the disposal of the infused glucose. Unfortunately, all these methods have obvious drawbacks and are subject to varying degrees of imprecision; these drawbacks, reviewed by Rizza, Mandarino and Gerich (1981 a), can be summarized as follows. First, the interpretation of the glucose-to-insulin ratio in glucose tolerance tests is difficult since there is a feedback loop between plasma glucose 
and insulin secretion and also because the relationship between the insulin level and its biological effect is not linear (Olefsky, 1981). Secondly, the decrease in plasma glucose concentration during the insulin tolerance test elicits the secretion of counterregulatory hormones (Garber et al., 1979). Third, the necessity of infusing epinephrine and propranolol or somatostatin along with glucose and insulin has potential effects on insulin action (Felig et al., 1979). The recently developed euglycemic insulin clamp technique for evaluating overall insulin sensitivity in man (De Fronzo, Tobin and Andres, 1979) obviates most of these limitations. With this technique, plasma insulin is increased to a predetermined constant level by a primed, continuous infusion of exogenous insulin, while plasma glucose is maintained at a constant euglycemic level by varying the infusion of the exogenous glucose. When endogenous glucose production is not entirely suppressed by exogenous insulin, glucose utilization is the sum of the remaining endogenous glucose production and the exogenous glucose infusion. The effect of insulin on glucose production and glucose utilization can be determined by using the euglycemic insulin clamp technique in conjunction with the isotopic measurement of glucose turnover (Rizza, Mandarino and Gerich, 1981 b). As insulin action may be altered due to changes in insulin sensitivity and/or insulin responsiveness (Kahn, 1978), it is necessary to examine the effect of several concentrations of insulin in order to determine its maximal effects as well as the concentration of insulin producing a half-maximal effect (Rizza, Mandarino and Gerich, $1981 \mathrm{~b}$ ). The aim of the present work was to adapt this technique to an in vivo study of the effects of insulin on glucose production and glucose utilization in the rat.

\section{Methods.}

Animals. - We used 12 female Wistar rats $(210 \pm 5 \mathrm{~g})$ bred in our laboratory. They were kept in a room at $24{ }^{\circ} \mathrm{C}$ with light from 06.00 to $20.00 \mathrm{~h}$ and had free access to water and chow pellets $165 \%$ carbohydrate, $11 \%$ fat and $24 \%$ protein).

Euglycemic insulin clamp technique. - Since spontaneous food consumption stopped at the onset of lighting, all the experiments were performed in the immediate postabsorptive period, i.e. between 08.00 and $11.00 \mathrm{~h}$. The rats were anesthetized with pentobarbitone $(30 \mathrm{mg} / \mathrm{kg}$ body weight IP) and one carotid artery was catheterized. Body temperature, continuously recorded with a telethermometer (Yellow Spring Instrument, Yellow Spring, Ohio), was maintained at $38^{\circ} \mathrm{C}$. Tracheotomy was systematically performed to avoid respiratory problems during anesthesia. Prior to any infusion, a priming IV bolus of $4 \mu \mathrm{Ci}$ of $\left[3^{-3} \mathrm{H}\right]$ glucose (New England Nuclear, Boston, Mass.) was given over $30 \mathrm{sec}$. Insulin (pig monocomponent insulin, Novo Industry, Copenhagen), dissolved in isotonic saline containing $1 \%$ bovine serum albumin (Sigma, St Louis, Mo.) and $\left[3-{ }^{3} \mathrm{H}\right]$ glucose, were then infused at a constant rate of $20 \mu \mathrm{l} / \mathrm{min}$ $(700 \mu \mathrm{U} / \mathrm{min}$ and $0.2 \mu \mathrm{Ci} / \mathrm{min})$ through a saphenous vein. Variable amounts of glucose were infused through the other saphenous vein with a Precidor pump 
(Infors AG, Basel) in order to clamp the blood glucose level at basal state concentration. The infusion of exogenous glucose (5\% glucose in water), begun $1 \mathrm{~min}$ after the initiation of insulin infusion, was empirically set at $1 \mathrm{mg} / \mathrm{min}$. We then sampled $30 \mu \mathrm{l}$ of blood from the carotid artery every $5 \mathrm{~min}$ and determined blood glucose concentrations within $35 \mathrm{sec}$. using a Yellow Spring glucose analyzer (YSI 32A, Yellow Spring, Ohio). To maintain euglycemia, adjustments in the exogenous glucose infusion rate were made by altering the percent dial of the Precidor pump, depending on the changes observed in the blood glucose concentrations. Initially, adjustments were made using a Hewlett-Packard calculator (HP 97) and computation based on the negative feedback control described by De Fronzo, Tobin and Andres (1979) and adapted to the rat by increasing the glucose distribution space $(27 \%$ of body weight). After experimenting with this technique, we stopped using the Hewlett-Packard calculator for adjusting the rates of exogenous glucose infusion. Indeed, we noticed that to reach the expected plateau of exogenous glucose infusion, steadystate glucose infusion was achieved sooner with a smaller coefficient of variation in blood glucose concentration $(2.4 \pm 0.3 \%$ ) when the rate of glucose infusion was left to the judgement of the manipulator during the first $20 \mathrm{~min}$. During the last $15 \mathrm{~min}$ of euglycemic clamp, some additional blood samples $(200 \mu \mathrm{l})$ were collected every 5 min to determine blood glucose specific activity and steady-state plasma insulin concentrations.

Endogenous glucose production. - We infused $\left[3^{3} \mathrm{H}\right]$ glucose to study endogenous glucose production because tritium in position $\mathbf{3}$ of the glucose molecule is lost to water in the glycolytic pathway and cannot be reincorporated into glucose (Altszuler et al., 1975 ; Katz et al., 1974). [3- $\left.{ }^{3} \mathrm{H}\right]$ glucose is thus considered to be an irreversible tracer.

Glucose turnover rate was determined in a group of 6 female rats in basal state, as described previously (Leturque, Gilbert and Girard, 1981). A priming dose of $4 \mu \mathrm{Ci}$ of $\left[3^{-3} \mathrm{H}\right]$ glucose was injected in $2 \mathrm{~min}$, followed by continuous infusion at a rate of $0.2 \mu \mathrm{Ci} / \mathrm{min}$ for $1 \mathrm{~h}$. The steady state of blood glucose specific radioactivity was established from 30 min onwards.

During the insulin clamp studies, a dynamic equilibrium also prevailed during the last $15 \mathrm{~min}$ of insulin infusion (results not shown).

In both the basal state and the euglycemic clamp studies, glucose appearance rate ( $\mathrm{Ra}$ ) equalled glucose disappearance rate (Rd); both rates were calculated by the isotope dilution equation : $R a=R d=F / S A$, where $F$ is the rate of tracer infusion $(\mathrm{nCi} / \mathrm{min})$ and $\mathrm{SA}$ is the specific activity of blood glucose at equilibrium ( $\mathrm{nCi} / \mathrm{mg}$ ). During euglycemic insulin clamp, the glucose appearance rate (Ra) represented the sum of endogenous glucose production and exogenous glucose infusion, and glucose disappearance rate ( $R d$ ) the rate of glucose utilization. The rate of endogenous glucose production was obtained by subtracting the amount of exogenous glucose infused from the isotopically determined glucose appearance rate.

Analytical techniques, - Blood samples for the determination of glucose specific activity were deproteinized with $\mathrm{Ba}(\mathrm{OH})_{2}-\mathrm{ZnSO}_{4}$ and immediately 
centrifuged. We used an aliquot of the supernatant to determine glucose concentration by a glucose oxidase method. Another aliquot of the supernatant was evaporated to dryness at $70^{\circ} \mathrm{C}$ to remove the tritiated water. The dry residue was dissolved in $0.2 \mathrm{ml}$ of water and counted with $10 \mathrm{ml}$ of Unisolve (Koch-Light Lab., Cornbrook, UK) in a liquid scintillation spectrometer.

Blood samples for insulin assay were immediately centrifuged at $4{ }^{\circ} \mathrm{C}$, and the plasma frozen at $-20^{\circ} \mathrm{C}$ for subsequent insulin radioimmunoassay with rat and pig insulin (fig. 1).

Statistics. - The results were expressed as mean \pm SEM. The significance of the difference was determined by Student's t-test.

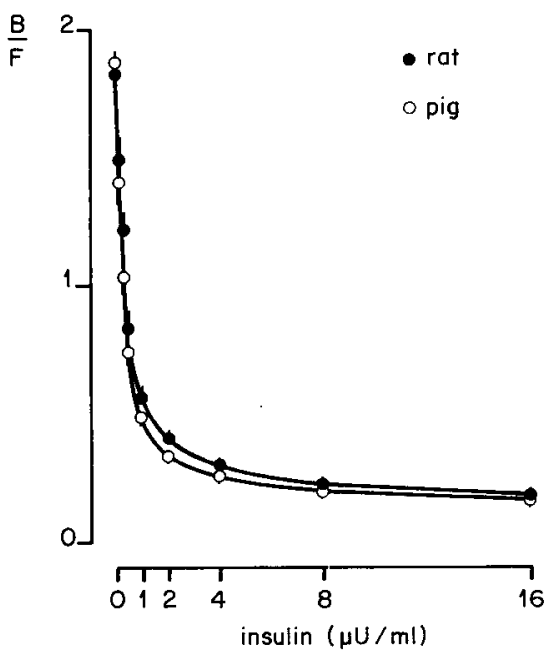

FIG. 1 .

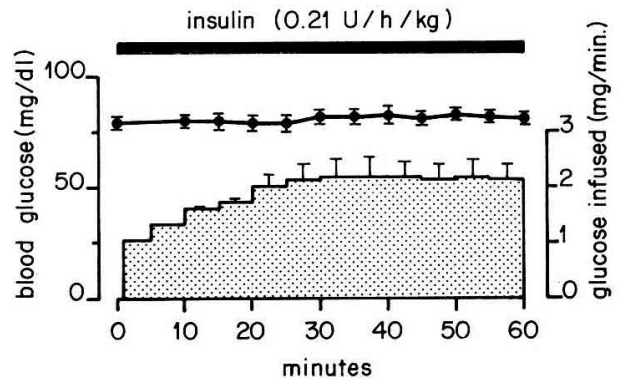

FIG. 2.

FIG. 1. - Standard curves for insulin radioimmunoassay. The assay procedure has been described previously (Leturque et al., 1980). Human insutin antiserum, 125 human insulin and various amounts of rat or pig insulin were used. Bound/free labelled insulin is expressed as a function of free insulin standards. Results are the mean \pm SEM of 4 separate assays.

FIG. 2. - Euglycemic insulin clamp in female rats. Blood glucose concentration (-) and exogenous glucose infusion rate ( Insulin infusion rate was $0.21 \mathrm{U} / \mathrm{h} / \mathrm{kg}$ body wt. Results are expressed as mean \pm SEM of 6 determinations.

\section{Results.}

The basal blood glucose concentrations in female rats were $78 \pm 1 \mathrm{mg} / \mathrm{dl}$ ( $\mathrm{n}=6$ ). The typical blood glucose concentrations and glucose infusion rates required to maintain euglycemia during continuous insulin infusion $(0.21 \mathrm{U} / \mathrm{h} / \mathrm{kg}$ body weight), using the euglycemic insulin clamp technique, are shown in figure 2. With constant glucose monitoring, blood glucose concentrations were 
maintained relatively constant at $81 \pm 2 \mathrm{mg} / \mathrm{dl}$. The coefficient of variation of glycemia was $2.4 \pm 0.3 \%$ for the 1 -hour study. The amount of exogenous glucose infused to maintain a constant blood glucose concentration increased gradually from $1 \mathrm{mg} / \mathrm{min}$ to a relatively stable plateau of $2.2 \mathrm{mg} / \mathrm{min}$ between 30 and $60 \mathrm{~min}$ of insulin infusion (fig. 2). The basal plasma insulin concentration in female rats was $48 \pm 4 \mu \mathrm{U} / \mathrm{ml}(\mathrm{n}=6)$. Following the continuous infusion of insulin at a rate of $0.21 \mathrm{U} / \mathrm{h} / \mathrm{kg}$ of body weight, the steady-state plateau of hyperinsulinemia, achieved after $30 \mathrm{~min}$ (results not shown), averaged $302 \pm 24 \mu \mathrm{U} / \mathrm{ml}$ (fig. 3). The stability of plasma insulin levels between 30 and $60 \mathrm{~min}$ was reflected by the relatively low coefficient of variation in the individual values : $8 \pm 2 \%$.

The rates of glucose production and glucose utilization in the basal state were $1.84 \pm 0.07 \mathrm{mg} / \mathrm{min}(\mathrm{n}=6)$. During the period of hyperinsulinemia the rates of glucose appearance (endogenous glucose production + exogenous glucose infusion) were $2.7 \pm 0.2 \mathrm{mg} / \mathrm{min}$ (fig. 3). Taking into account the rate of exogenous glucose infusion necessary to maintain euglycemia during insulin infusion, i.e. $2.2 \pm 0.3 \mathrm{mg} / \mathrm{min}$, the rate of endogenous glucose production was estimated as $0.5 \pm 0.05 \mathrm{mg} / \mathrm{min}$ (fig. 3). During the period of hyperinsulinemia, endogenous glucose production was suppressed by $76 \pm 3 \%$ and glucose utilization was increased by $53 \pm 10 \%$ (fig. 3 ).
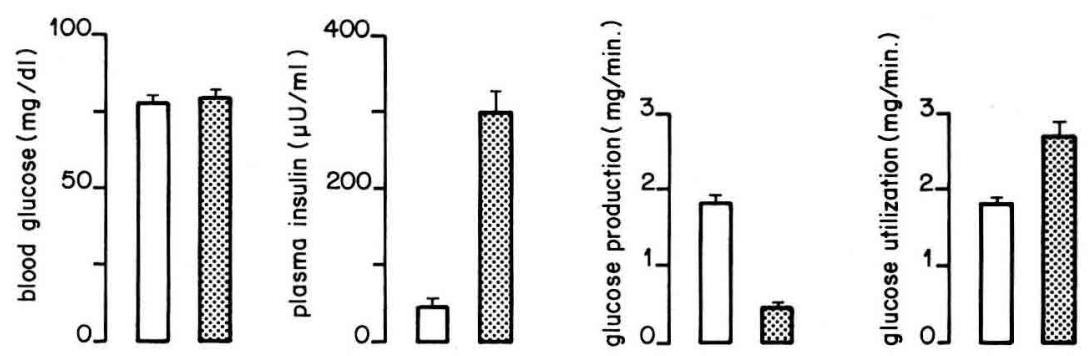

FIG. 3. - Blood glucose levels, plasma insulin concentrations, glucose production and glucose utilization in female rats in basal state $(\square)$ and during euglycemic insulin clamp $(\square)$. Insulin infusion rate was $0.21 \mathrm{U} / \mathrm{h} / \mathrm{kg}$ body wt. Results are mean $\pm S E M$ of 6 determinations.

\section{Discussion.}

These preliminary results clearly show that the euglycemic insulin clamp technique coupled with the isotopic measurement of glucose turnover can be applied to rat. The experiment lasted about $1 \mathrm{~h}$, and the euglycemic clamp was easily reached $30 \mathrm{~min}$ after the beginning of insulin infusion. A total of about $1 \mathrm{ml}$ of blood was needed, eight $30-\mu \mathrm{l}$ samples for glucose monitoring and four 200- $\mu$ l samples for glucose turnover and plasma insulin assay. This was quite an acceptable amount for an animal the size of the rat.

Previous studies using the euglycemic insulin clamp technique in man have shown that endogenous glucose production is completely suppressed at a 
plasma insulin concentration of $100 \mu \mathrm{U} / \mathrm{ml}$, and that glucose utilization increases 4 to 5-fold over the basal values (Rizza, Mandarino and Gerich, 1981 b). Pork insulin seems to be much less active in rat than in man since endogenous glucose production was suppressed by only $76 \%$ and glucose utilization was increased by only $53 \%$ at a plasma insulin concentration of $300 \mu \mathrm{U} / \mathrm{ml}$. The reasons for this difference are not known, but it must be recalled that basal plasma insulin levels and glucose turnover rates in $\operatorname{man}(10 \mu \mathrm{U} / \mathrm{ml}$ and $2 \mathrm{mg} / \mathrm{min} / \mathrm{kg})$ are much lower than in rats $(40 \mu \mathrm{U} / \mathrm{ml}$ and $9 \mathrm{mg} / \mathrm{min} / \mathrm{kg})$. The use of only a single insulin concentration to assess insulin action provides limited data on the underlying mechanism (Kahn, 1978). Changes in sensitivity and responsiveness to insulin can only be distinguished by examining the insulin dose-response curve in vivo. With the euglycemic clamp technique, two methods have been used to determine the dose-response characteristics of the effects of insulin on glucose production and glucose utilization in man : 1) the infusion of various doses of insulin in a given individual over 3 to 4 separate days (Kolterman et al., 1980, 1981) and 2) the infusion of insulin for $8 \mathrm{~h}$ on the same day at sequential rates (Rizza, Mandarino and Gerich, 1981 b, 1982). The total amount of blood which can be sampled in a rat is limited to 1 or $2 \mathrm{ml}$, so that the insulin dose-response curves must be performed on separate days or on separate animals. This technique has been used successfully in studying the mechanisms of insulin resistance during pregnancy in the rat. Preliminary results show that the dose-response curve for the effect of insulin on glucose production and glucose utilization was shifted to the right. This confirms previous studies (Leturque et al., 1980) suggesting the existence of a decrease in the insulin sensitivity of the liver and the peripheral tissues.

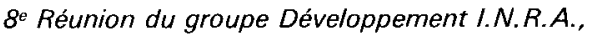
Tours, 12-13 mai 1982.

Acknowledgements. - We are grateful to Dr. A. Kervran for the gift of the insulin antiserum.

Résumé. Une méthode de mesure de la sensibilité à l'insuline in vivo chez le rat anesthésié : la technique du clamp euglycémique hyperinsulinémique couplé à la mesure isotopique du taux de renouvellement du glucose.

La technique du clamp euglycémique couplé à la mesure isotopique de l'utilisation du glucose (glucose $\left(3^{3} \mathrm{H}\right]$ ) décrite initialement chez l'Homme a été adaptée chez le Rat. Cette technique permet de caractériser et de quantifier in vivo la sensibilité à l'insuline. Trente minutes après le début du clamp, la vitesse de perfusion du glucose exogène, l'activité spécifique du glucose sanguin et la concentration de l'insuline plasmatique atteignent un plateau et ne varient plus pendant les $30 \mathrm{~min}$ suivantes. La glycémie est maintenue constante à son niveau de base et présente des fluctuations de l'ordre de $2,3 \%$. A l'état basal, les rattes anesthésiées au pentobarbital présentent, pour une insuline plasmatique de $48 \pm 4 \mu \mathrm{U} / \mathrm{ml}$, une utilisation du glucose de $1,84 \pm 0,07 \mathrm{mg} / \mathrm{min}$. Au cours du clamp euglycémique l'insulinémie atteint $302 \pm 24 \mu \mathrm{U} / \mathrm{ml}$, l'utilisation de glucose est augmentée de $53 \pm 10 \%$ et la production endogène de glucose est diminuée de $76 \pm 3 \%$. En étudiant les effets de plusieurs concentrations d'insuline sur des groupes de rattes dif- 
férentes, il sera possible de caractériser l'insulino résistance durant la gestation chez la ratte, et de connaître les tissus responsables de cette insulino-résistance (tissus périphériques ou foie).

\section{References}

ALTSZULER N., BARKAI A., BJERKNES C., GOTTLIEB B., STEELE R., 1975. Glucose turnover values in the dog obtained with various species of labelled glucose. Am. J. Physiol., 229, 1662-1667.

DE FRONZO R. A., TOBIN J. D., ANDRES R., 1979. Glucose clamp technique : a method for quantifying insulin secretion and resistance. Am. J. Physiol, 237, E214-E223.

FELIG P., SHERWIN R. S., SOMAN V., WAHREN J., HENDLER R., SACCA L., EIGLER N., GOLDBERG D., WALESKY M., 1979. Hormonal interactions in the regulation of blood glucose. Rec. Progr. Horm. Res., 35, 501-532.

GARBER A. J., CRYER P. E., SANTIAGO J. V., HAYMOND M. W., PAGLIARA A. S., KIPNIS D. M., 1976. The role of adrenergic mechanisms in the substrate and hormonal response to insulin-induced hypoglycemia in man. J. clin. Invest., 58, 7-15.

HARANO Y., OHGAKU S., HIDAKA H., HANEDA K., KIKKAWA R., SHIGETA Y., ABE H., 1977. Glucose, insulin and somatostatin infusion for the determination of insulin sensitivity. J. clin. Endocrinol. Metab., 45, 1124-1127.

KAHN C., 1978. Insulin resistance, insulin insensitivity and insulin unresponsiveness : a necessary distinction. Metabolism, 27, 1893-1902.

KATZ J., DUNN A., CHENOWETH M., GOLDEN S., 1974. Determination of synthesis, recycling and body mass of glucose in rats and rabbits in vivo with ${ }^{3} \mathrm{H}$ and ${ }^{14} \mathrm{C}$ labelled glucose. Biochem. J., 142, 171-183.

KOLTERMAN O. G., INSEL J., SAEKOW M., OLEFSKY J. M., 1980. Mechanisms of insulin resistance in human obesity : evidence for receptor and postreceptor defects. J. clin. Invest., 65, $1272-1284$.

KOLTERMAN O. G., GRAY R. S., GRIFFIN J., BURSTEIN P., INSEL J., SCARLETT J. A., OLEFSKY J. M., 1981. Receptor and postreceptor defects contribute to the insulin resistance in noninsulin-dependent diabetes mellitus. J. clin. Invest., 68, 957-969.

LETUROUE A., FERRE P., SATABIN P., KERVRAN A., GIRARD J., 1980. In vivo insulin resistance during pregnancy in the rat. Diabetologia, 19, 521-528.

LETUROUE A., GILBERT M., GIRARD J., 1981. Glucose turnover during pregnancy in anaesthetized post-absorptive rats. Biochem. J., 196, 633-636.

NAGULESPARAN M., SAVAGE P., UNGER R., BENNETT A., 1979. A simplified method using somatostatin to assess in vivo insulin resistance over a range of obesity. Diabetes, 28, 980983.

OLEFSKY J. M., 1981. Insulin resistance and insulin action. An in vitro and in vivo perspective. Diabetes, 30, 148-162.

REAVEN G., BERSTEIN R., DAVIS B., OLEFSKY J. M., 1976. Non-ketotic diabetes mellitus : insulin deficiency or insulin resistance. Am. J. Med., 60, 80-88.

RIZZA R. A., MANDARINO L. J., GERICH J. E., 1981 a. Mechanisms of insulin resistance in man. Assessement using the insulin dose-response curve in conjunction with insulinreceptor binding. Am. J. Med., 70, 169-176.

RIZZA R. A., MANDARINO L. J., GERICH J. E., 1981 b. Dose-response characteristics for effects of insulin on production and utilization of glucose in man. Am. J. Physiol., 240, E630-E639.

RIZZA R. A., MANDARINO L. J., GERICH J. E., 1982. Cortisol-induced insulin resistance in man : impaired suppression of glucose production and stimulation of glucose utilization due to a postreceptor defect of insulin action. J. clin. Endocrinol. Metab., 54, 131-138. 